\title{
First incidence of a spider mite, Oligonychus tylus (Baker \& Pritchard), in date palm (Phoenix dactylifera L.) groves of Kachchh in Gujarat, India
}

\author{
C.M. Muralidharan*, D.A. Baidiyavadra, Kapil Mohan Sharma and N. Srinivasa ${ }^{1}$ \\ Date Palm Research Station, Sardarkrushinagar Dantiwada Agricultural University Mundra-Kachchh-370 421, \\ Gujarat, India \\ ${ }^{1}$ University for Agricultural Sciences, GKVK Campus, Bengaluru-560 065, Karnataka, India.
}

(Manuscript Received: 08-05-2020, Revised: 24-06-2020, Accepted: 06-07-2020)

Keywords: Date palm, Kachchh, Oligonychus tylus, webbing mite

Date palm (Phoenix dactylifera L.) is one of the oldest cultivated crops of the desert region. It is believed to be originated in Mesopotamia (Southern Iraq) during $5000 \mathrm{BC}$ (Zohary and Hopf, 2000) and it is commercially cultivated in more than 40 countries with 100 million hectares with a production of 7-8 million tones of dates (FAO Stat, 2017). In India, date palm is commercially cultivated inthe western border, i.e., the coastal belt of Kachchh district of Gujarat having about 2.0 million trees producing 17 thousand tons of fresh dates (Anonymous, 2018). This region enjoys the monopoly of the commercial cultivation of date palm and it is one of the subsistent crops of the agrarian community of western part of India.

One hundred and twelve species of insect and mite pests have been reported worldwide on date palm (El-Shafie, 2012). However, in the coastal belt of Kachchh, red palm weevil (Rhynchophorus ferrrugineus Oliver; Coleoptera: Curculionidae), rhinoceros beetle (Oryctus rhinoceros L.; Coleoptera: Scarabaeidae) and date palm white scale (Parlatoria blanchardi Targionii Tozzetii; Hemiptera: Diaspididae) - cause economic damage (Muralidharan, 1993; Muralidharan et al., 2000).

Mite infestation and damage to date palms were first recorded in Israel in the Southern Arava valley during the late 1970s (Gerson et al., 1983) and fifteen species of phytophagous mites have been reported from various date palm growing areas of the world (El-Shafie, 2012). However, no economic damage of mite incidence has reported so far from this crop from the Indian subcontinent.

A survey conducted by the Date Palm Research Station (DPRS), Sardarkrushinagar Dantiwada Agricultural University (SDAU), Mundra, during May-2016 has brought to the notice, certain mite species infesting fruit bunches from Dhrub village of Mundra taluk for the first time. The fruits were near to colour breaking stage (khalal), and severe mite infestation/damage was evident with spinning webs around fruit bunch with dusty appearance (Fig. 1). Extensive mite feeding on date fruit with webbing and mites' shed skins get covered by dust particles (Fig. 2). In addition to this, the highly turbulent wind carrying dust during summer months in the region was also responsible for this dusty appearance, which reduces the marketability of fruits.

The mite specimens were identified morphologically as Oligonychus tylus by the All India Network Project on Agricultural Acarology at the University of Agricultural Sciences, Bangalore using 10 male and five female microscopic slide-mounted mite specimens. Also, molecular data (for the mitochondrial gene) were

*Corresponding Author: muralidharancm@yahoo.com 


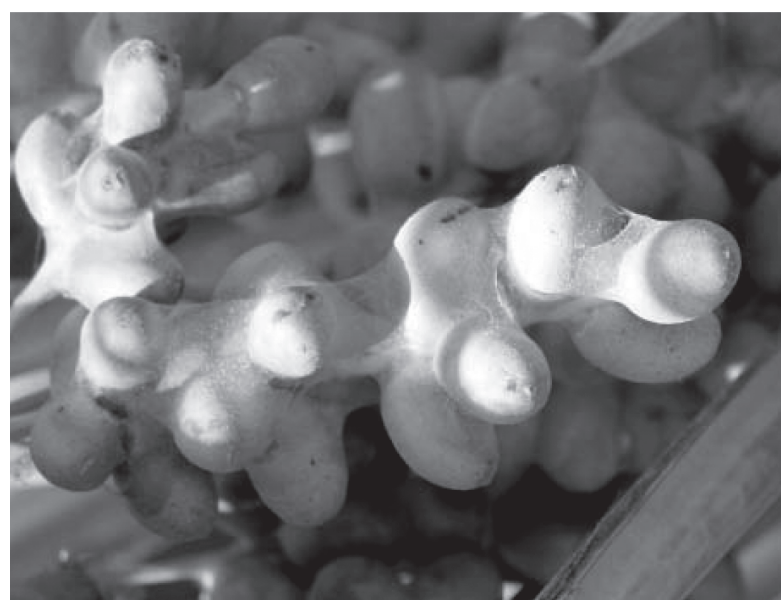

Fig. 1. Spinning webs of Oligonychu stylus on date fruits

generated by DNA extraction (by CTAB method), PCR amplification with COI primers, Sanger sequencing and BLAST analysis followed by sequence deposition (accessioned) in NCBIGenBank database. BLAST analysis showed a maximum of 98.53 per cent identity matching with other four sequences of Oligonychus tylus from India, available in the Gen Bank database. Slide mounted specimens are preserved as voucher specimens in the mite repository (UAS-B:1952 Dt. 02.05.2016 and UAS-B:1963 Dt. 23.05.2016) of University of Agricultural Sciences, Bangalore and available for retrieval or review.

To ascertain the incidence and severity of the damage, a roving survey was conducted during April-May, 2017 when fruits were of late kimri or early khalal stage. Twenty five villages distributed over four taluks were surveyed and monitored 118 orchards for mite infestation. The numbers of orchards were selected as per the cluster sampling method (Taherdoost, 2016) drawing approximately 25 per cent of the total orchards in each taluk and the villages were selected randomly. An orchard having 600-800 palms were considered for survey and sampling. The severity of mite infestation was computed by visual observation of webbing intensity on fruit bunches of infested palms and categorized as severe $(\mathrm{S})$ if the webbing covered more than 50 per cent of the fruit bunch, medium (M) (10-50\% fruit bunches) and mild (Ml) $<10 \%$ of fruit bunches per palm. Twenty five palms were

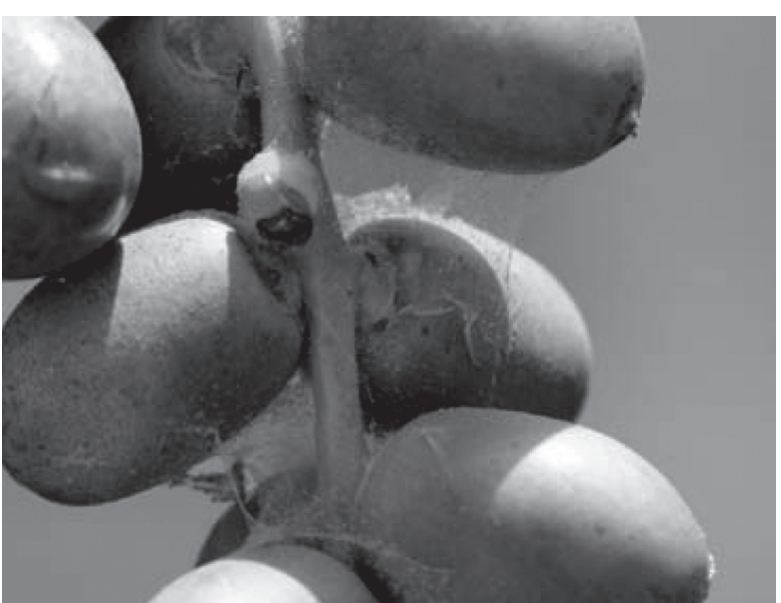

Fig. 2. Damaged fruit skin of dates by $O$. tylus

selected from each mite affected orchards, and five bunches per palm were selected randomly for assessing the damage.

The varietal response of mite infestation on five different varieties/clone at DPRS, Mundra was recorded and expressed as per cent webbing index (PWI) as per the procedure suggested by McKinney (1923) with slight modification on five randomly selected bunches per palm repeated on three palms per variety. The observation was taken at 15 days interval starting from $2^{\text {nd }}$ week of April to $2^{\text {nd }}$ week of May. The per cent webbing index (PWI) was derived on fruit bunches by applying a web rating scale of $0-10(0=$ no webbing; $10=100 \%$ webbing in fruit bunches) and an index was derived as per the following formula.

PWI $=\frac{\text { Sum of all numerical score }(\text { Total score })}{\text { Max. Score (Highest score observed }} \times 100$

The survey conducted on 118 orchards spread over 25 villages of four taluks of Kachchh district of Gujarat, presented in Table 1, revealed that the incidence of $O$. tylus was spread over 63.55 per cent of the orchards and 43 orchards (36.45\%) were free from mite incidence. Among different taluks, the highest incidence was observed in Anjar taluk (73.08 \%), followed by Mundra, Bhuj and Mandvi taluks with an incidence of 64.32, 55.56 and 50.00 per cent respectively. Among the infested orchards (75), 18.64 per cent orchards shown severe mite 
First incidence of spider mite in date palm

Table 1. Incidence and severity of spider mite damage on different villages of Kachchh (Apr-May, 2017)

\begin{tabular}{|c|c|c|c|c|c|c|}
\hline \multirow[t]{2}{*}{ Taluk } & \multirow[t]{2}{*}{ Villages } & \multirow{2}{*}{$\begin{array}{c}\text { Number of } \\
\text { orchards visited }\end{array}$} & \multirow{2}{*}{$\begin{array}{c}\text { Mite } \\
\text { incidence* }\end{array}$} & \multicolumn{3}{|c|}{ Intensity } \\
\hline & & & & Severe & Medium & Mild \\
\hline Anjar & Khedoi, Anjar, Veedi, Satapar, Ratnal (05) & 26 & $19(73.08)$ & $06(23.07)$ & $04(15.38)$ & $09(34.61)$ \\
\hline Mandvi & Guthiyali, Bidada, Mankuva, NaniKhakar (04) & 12 & $06(50.00)$ & $01(8.33)$ & $03(25.00)$ & $02(16.67)$ \\
\hline \multirow[t]{2}{*}{ Mundra } & Dhrub, Zarpara, Borana, Kapaya, Vadala, & & & & & \\
\hline & Bhujpar, Bharapar, Mangra, Sadau, Navinal (10) & 62 & $40(64.52)$ & $11(17.74)$ & $10(16.12)$ & $19(30.64)$ \\
\hline \multirow[t]{2}{*}{ Bhuj } & Reldi, Kera, Kukma, Jhumkha, Baldiya, & & & & & \\
\hline & Mankuva (06) & 18 & $10(55.56)$ & $04(22.22)$ & $01(5.56)$ & $05(27.77)$ \\
\hline Total (4) & 25 & 118 & $75(63.55)$ & $22(18.64)$ & $18(15.25)$ & $35(29.66)$ \\
\hline
\end{tabular}

Note: Severe ( $>50 \%$ webbing bunch ${ }^{-1}$ palm $\left.^{-1}\right)$; Medium $=10-50 \%$ and Mild $<10 \%$

*Values in parenthesis are in percentage value

infestation $(>50 \%$ webbing per fruit bunches per palm), however, 15.25 per cent orchards registered medium infestation level (10-50\% webbing), and 29.66 per cent orchards revealed mild infestation $(<10 \%$ webbing). Among the taluks, Anjar recorded maximum orchards having severe mite incidence $(23.07 \%)$, followed by Bhuj $(22.22 \%)$ and Mundra (17.74\%). In Mandvi taluks, the severity of the mite incidence among the different orchards under survey was lowest $(8.33 \%)$.
The intensity of webbing observed on five different varieties/clones of date palm, starting from $2^{\text {nd }}$ week of April to $2^{\text {nd }}$ week of May presented in Table 2. The results indicated the highest webbing index of 41.93 per cent observed on cultivar KCCL 63, which was at par with cultivar KCCL 169 and cultivar ADP-1. Barhee showed lowest webbing index initially, which was at par with cultivar KCCL 091. However, no significant difference was observed among different varieties/clones.

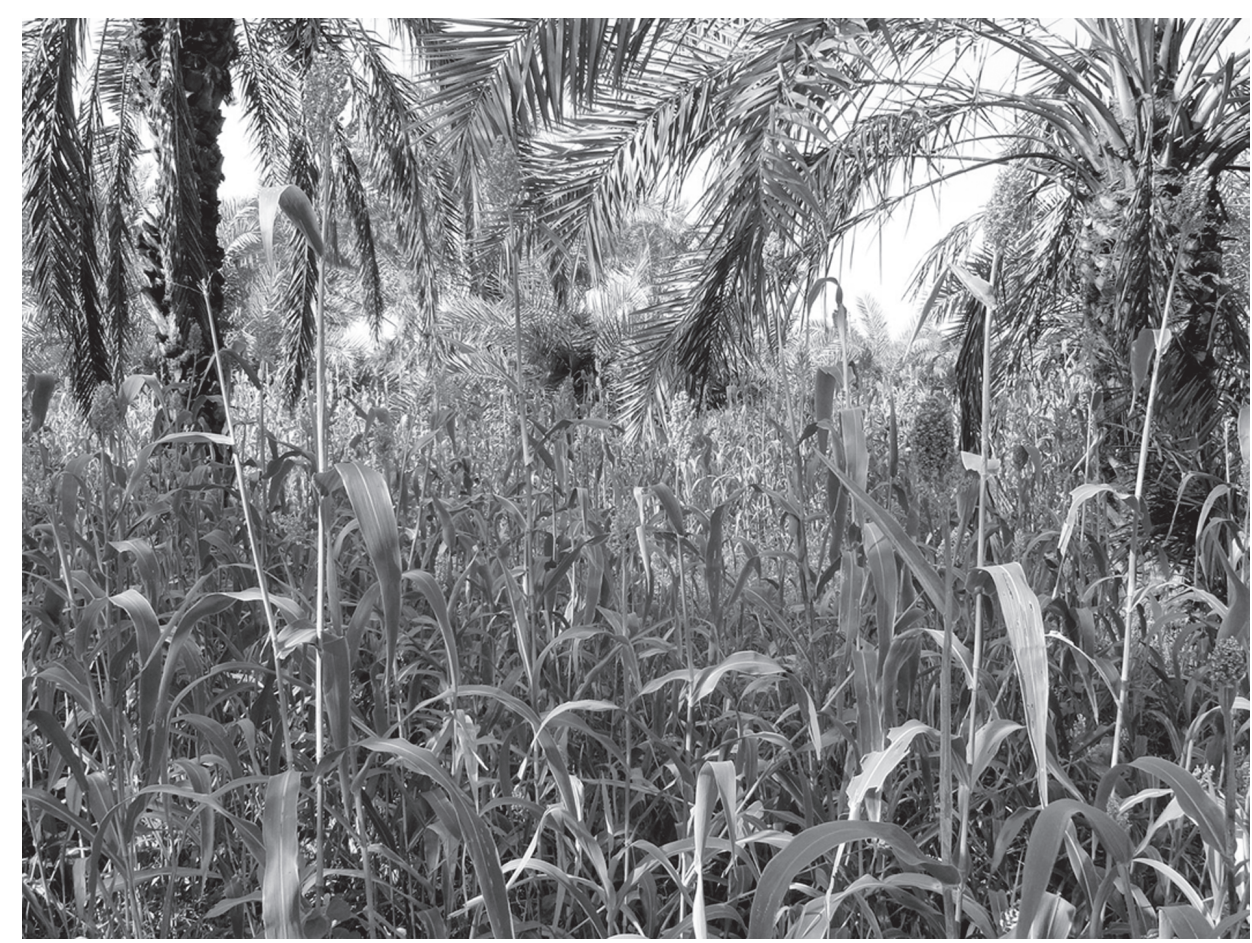

Fig. 3. Intercropping of fodder sorghum with date palm 
Table 2. Webbing index in different periods on different varieties/clones

\begin{tabular}{|c|c|c|c|}
\hline \multirow[t]{2}{*}{ Varieties/clones } & \multicolumn{3}{|c|}{ \% Webbing index } \\
\hline & $2^{\text {nd }}$ week of April" & $4^{\text {th }}$ week of April ${ }^{*}$ & $2^{\text {nd }}$ week of May $^{*}$ \\
\hline KCCL 63 & $40.20(41.93)$ & $50.12(58.89)$ & $47.78(54.86)$ \\
\hline KCCL 169 & 40.32 (41.9) & $48.71(56.46)$ & $40.98(43.03)$ \\
\hline ADP-1 & $34.12(31.85)$ & $50.64(59.72)$ & $41.18(43.75)$ \\
\hline Barhee & $21.134(13.33)$ & $48.21(55.56)$ & $51.77(61.67)$ \\
\hline KCCL 091 & $28.96(24.44)$ & $50.15(58.89)$ & $43.91(48.33)$ \\
\hline S.Em \pm & 3.91 & 2.97 & 4.46 \\
\hline C.D.@5\% & 12.48 & NS & NS \\
\hline C.V. \% & 20.55 & 10.37 & 17.13 \\
\hline
\end{tabular}

Note: *Data are arc-sine transformed;Values in the parentheses are original values.S.Em = Standard error of Mean, C.D. @ $5 \%=$ Critical difference at 5\% level of significance, C.V. = Coefficient of variation

Oligonychus senegalensis Gutierrez and Etinne and $O$. afrasiaticus $\mathrm{McGregor}$ are the two other dominant spider mite species occurring on date palm (Palevsky et al., 2003) causing economic damage. However, in date groves of Kachchh we could observe only $O$. tylus, which is considered as a dubious species (Gupta and Gupta, 1994) and already reported from India on Musa sapientum L. of family Musaceae, Panicum maximum and Zea mays L. of family Poaceae, Cocos nucifera L. and Areca catechu L. of family Arecaceae (Zeity, 2015). This species is also reported from Mauritius on Panicum maximum Jacq. (Baker and Pritchard, 1960) and sorghum (Sorghum bicolour L.) both of family Poaceae by Sirsikar and Nagabhushan (1989).

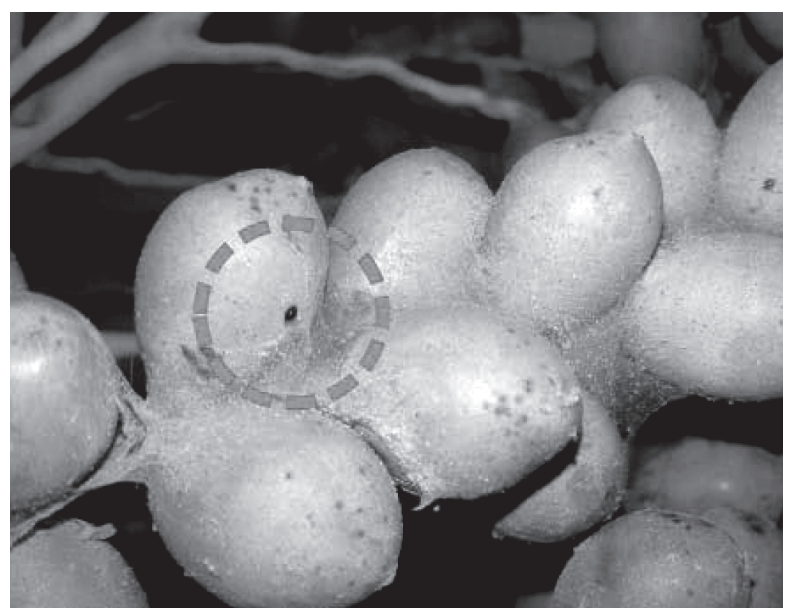

Fig. 4. Predatory coccinellid Stethorus sp. in the web
Interestingly, in Kachchh cultivating fodder sorghum as an intercrop of date palm is a common practice to feed their domestic animals (Fig. 3). Even though O. tylus has been reported on date palm in Israel (Gerson et al., 1983), but in their subsequent publication, it was reported that the species was misidentified as it was originally $O$. senegalensis (Palevsky et al., 2003). Hence, the incidence and widespread fruit damage by $O$. tylus on date palms is the first report from India and the world.

No predatory Phytoseiids was observed in the mite colony. However, mite coccinellid predator Stethorus sp. (Coleoptera: Coccinellidae) was observed in the webs (Fig. 4). More detailed studies have to be initiated to understand the bio-ecology of mite faunal complex existed in the date groves of Kachchh.

\section{Acknowledgement}

The authors acknowledge ICAR for necessary support through All India Coordinated Trial on Arid Zone Fruits for conducting this survey.

\section{References}

Anonymous, 2018. Area and production in different talukas of Kachchh. Deputy Director of Horticulture, Bhuj, Government of Gujarat.

Baker, E.W. and Pritchard, A.E. 1960. The tetranychoid mites of Africa. Hilgardia 29(11): 455-448.

El- Shafie, H.A.F. 2012. Review: list of arthropod pests and their natural enemies identified worldwide on date palm, Phoenix dactylifera L. Agriculture and Biology Journal of North America 3(12):516-524. 
FAO, 2017. Food and Agriculture organization of the United Nations, 2017. Worldwide dates production stations. http://faostat/servlet.

Gerson, U., Venezian, A. and Blumberg, D. 1983. Phytophagous mites on date palms in Israel. Fruits 38:133-135.

Gupta, S.K. and Gupta, Y.N. 1994. A taxonomic review of Indian Tetranychidae (Acari: Prostigmata) with descriptions of new species, redescriptions of known species and key to genera and species. Memoirs of the Zoological Survey of India 18(1): 1-196.

Taherdoost, H., 2016. Sampling methods in research methodology: How to choose a sampling technique for research. International Journal of Academic Research in Management 5: 18-27.

McKinney, H.H. 1923. Influence of soil temperature and moisture on infection of wheat seedlings by Helminthosporium sativum. Journal of Agricultural Research 26: 195-217.

Muralidharan, C.M. 1993. Scale insects of date palm (Phoenix dactylifera) and their natural enemies in the date groves of Kachchh (Gujarat). Plant Protection Bulletin 45(2\&3): 31-33.

Muralidharan, C.M., Sodagar, N.N. and Vaghasia, U.R. 2000. Survey, distribution, extent of damage, field behavior and biology of red palm weevil, Rhychophorus ferrrugineus Oliv. on date groves of Kachchh (Gujarat). GAU Research Journal 25(2):9-14.

Palevsky, E., Ucko, O., Peles, S., Yablonski, S. and Gerson, U. 2003. Species of Oligonychus infesting date palm cultivars in the southern Arava Valley of Israel. Phytoparasitica 31:144-153

Sirsikar, A.N. and Nagabhushanam, R. 1989. Biology of Oligonychus tylus:a potential mite pest of sorghum and other cereals. Journal of Acarology 11: 95-99.

Zeity, M. 2015. Tetranychid mite fauna of major agroecosystems in Karnataka and some aspects of molecular characterization of selected genera of spider mites. Ph.D. Thesis submitted to University of Agricultural Sciences, Bangalore, India, 240p.

Zohary, D. and Hopf, M. 2000. Domestication of Palms in the Old World. The Origin and Spread of Cultivated Plants in West Asia, Europe and Nile Valley. Oxford University Press, Oxon, UK. 